OPEN ACCESS

International Journal of Advanced Economics

P-ISSN: 2707-2134, E-ISSN: 2707-2142

Volume 3, Issue 2, P.No. 58-71, June 2021

DOI: $10.51594 /$ ijae.v3i2.236

Fair East Publishers

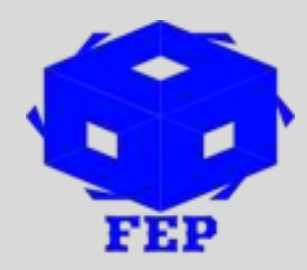

Journal Homepage: www.fepbl.com/index.php/ijae

\title{
COMPARATIVE STUDY OF AGRICULTURAL EXTENSION SYSTEM OF NIGERIA AND THE GAMBIA
}

\author{
Fatty, L. K M ${ }^{1,2}$, Prof. Idu Ogbe Ode ${ }^{1}$, Bejamin Gowon Ahule ${ }^{1}$, Akuhwa Tor ${ }^{1}$
}

${ }^{1}$ Centre for Food Technology and Research, Department of Sociology; Faculty of Social Sciences, Makurdi, Nigeria

${ }^{2}$ Benue State University and University of the Gambia.

*Corresponding Author: Fatty, L. K M

Corresponding Author Email: 1kmfatty@utg.edu.gm

Article Received: 02-06-20 Accepted: 15-06-21

Published: 21-06-21

Licensing Details: The author retains the right to this article. The article is distributed under the terms of the Creative Commons Attribution-Non-Commercial 4.0 License (http://www.creativecommons.org/licences/by-nc/4.0/) which permits non-commercial use, reproduction, and distribution of the work without further permission provided the original work is attributed as specified on the Journal open access page.

\begin{abstract}
This study focuses on the analysis of Nigeria and The Gambia National extension policies and system. The study discussed three main themes (mission and goals, approach and functions, and clienteles). The study found that both two countries does not adopt legislated or formal national extension policy rather implied policies which were garnered, feasible, for the two countries through their government publications and published researched studies from academic and recognized developmental institutions. Generally, the analysis found that the two countries extension missions and goals focused on improving profitability of agricultural business and increasing output volumes; market share in achieving to enhancing quality of life and agricultural development. In terms of approaches and functions, the study observed that public sector extension in the two countries is undergoing transformation including decentralization and outsourcing extension services in the context of adopting a pluralistic system of extension delivery. While up to six models of extension are a commonly applied in the two countries, the dominant context is pluralism around public, private and NGO-based services. The dominant clientele was stated to be women and small- and medium-scale farmers. However, main barriers limiting women's participation are still insufficiently addressed. The study concludes that it is important for the two countries authorities, perhaps supportively, to develop and establish formal extension policies that will manifest their vision, mission, goals and methods to provide a stable agenda within which targeted clientele and be purposively supported in the pursuit of sustainable agricultural development.
\end{abstract}


Keywords: Extension, Extension Policy, Nigeria, The Gambia, Mission and Goals, Approach and Function, Clientele.

\section{INTRODUCTION \& LITERATURE REVIEW}

The importance of agriculture as a viable driver for economic development and sustainable livelihood is widely acknowledged. In Africa for example, agriculture employs not less than $65 \%$ of the total labour force, while accounting for about one-third of the gross domestic product (World Bank, 2008). Despite this substantial contribution of agriculture to the economy, the labour productivity in agriculture remains low in sub-Saharan Africa. The average value added per worker in 34 sub-Saharan Africa nations is US\$ 318, relative to the global average of US\$ 1,000 for the same period (Rosen \& Shapouri, 2012). This lagging pace of Africa undoubtedly constitutes a major contributing factor to the entrenched poverty ravaging the region. With specific reference to West Africa, the main focus of this study, agriculture is particularly essential to the economic growth and development. The sector provides employment for an average of $60 \%$ of the labour force, while delivering not less than $80 \%$ of the food requirements for the teeming population of about 300 million people in the region (World Bank, 2011). Agriculture also serves the main source of raw materials for processing and manufacturing companies, thereby contributing about $15.3 \%$ to export of goods and services in ECOWAS (International Monetary Fund-IMF, 2010). With the exclusion of crude oil exportation from Nigeria, agriculture contributes not less than $30 \%$ of the export earnings, while accounting for about $21 \%$ of the regional import bill (United Nations Economic Commission of Africa, 2010). Also, the average contribution of the sector to the Gross Domestic Product (GDP) of West African countries is $35 \%$, albeit with noteworthy disparities among the countries.

\section{The Problem Statement}

Notwithstanding all these contributions, the productivity and yields of agriculture in West Africa are generally low as compared to those of other developing regions of the world. The cereal production levels of all the West African countries, except for Ghana, are still below the 1990 cereal production levels for Latin America and South Africa (FAO, 2012). This unfortunate condition has been attributed to a number of factors, including: poor levels of mechanization, inadequate fertilizer usage, insufficient access to improved seed, dependence on rain-fed agriculture, and poor management of water.

In addition, the challenges further affecting agriculture on global and local scales include: population growth escalation, climate change effects, land tenure issue, increasing number of HIV/AIDS-infected farmers, and issues concerning market liberalization and access. Within these challenges, the importance of agricultural extension in advancing agricultural developments, particularly in West Africa, inclusive of Nigeria and The Gambia, seems currently downplayed both practically and in literature and governmental reports. A recent account from the Worldwide Extension Study (2011: 1) categorically indicated a "lack of information on extension for several West African countries".

\section{Objective}

The paper seeks to help seek on the premise that extension is particularly important to the success of any national agricultural production endeavours; and its constant re-analysis and reinvention should be given high priority by governments. 


\section{Significance of the Analysis}

Effective engagement of extension in agricultural development requires a change of extension approach from the singular, narrowly defined model of public provision of technology transfer services, which is widely acknowledged to have outlived its usefulness as a sole strategy in achieving effective and competitive agricultural development. Extension, in the current dispensation, faces challenges of tackling objectives ranging from: promoting environmentally sustainable agricultural practices (Alex, Zijp \& Bylerlee, 2002); responsively and efficiently linking of farmers to local and international markets; reducing the vulnerability of the rural poor and enhancing their voices (Farrington, Kidd and Beckman, 2002); viewing agriculture as part of an all-embracing set of rural growth strategies, including non-farm employment and enterprise expansion (Rivera, Qamar \& Crowder, 2001); pairing technology transfer with other services relating to both input and output markets (Neuchatel Group, 2002); the need to develop competence among farmers, including not only training, but also reinforcement of innovation developments, establishment of linkages between farmers and other organizations, as well as development of institutional and organizational supports to strengthen the bargaining power (Sulaiman \& Hall, 2003).

In view of all these responsibilities for extension, this work suggests the necessity and the need for an overarching national institutional analysis of action in the form of extension policy and system in any given country. In line with this suggestion, the FAO Global Consultation on Agricultural Extension argued that: "all national governments should develop and periodically review their agricultural extension policy and systems. The policy and system should include the goals of agricultural extension, the responsible agencies and personnel, the clientele to be served, the broad programmatic area to be addressed and other relevant guidelines. In developing national agricultural extension policies, representatives of all major groups of farmers should be directly involved and other relevant agricultural organizations should be consulted. By pursuing a wide-ranging policy, countries can expect the extension system to contribute to increasing agricultural productivity and farm incomes, and to improving the quality of life of most rural farm households in pursuit of the general goal of growth with equity" (Swanson, 1990: 11).

\section{METHODOLOGY}

In response to this, the study makes a comparison existence of national extension policies in Nigeria and The Gambia and analysis their various contents. Elements suggested by the FAO as "issues that extension policy should address" will be used as the analysis for the study (FAO, 1998: 6). In cases where no formal policies exist, extension policy is gathered from various government documents available online regarding agricultural, rural and extension policies and those concerning agricultural, rural, research and extension projects to determine the de facto policies.

To effectively analyse extension policy and system, the review examines and then establishment on some feasible criteria for the analysis. The FAO (1998) suggested a detailed criterion of the policies' mission and goals, approach and functions, subject-matter coverage, geographical coverage, clienteles, organizational issues, staffing issues, funding arrangements, and its stability. However, the Neuchatel Group (1999) suggested that mission and goals, approaches and functions, and clientele were the most critical elements of consideration in any analysis of multiple policies. These, then, were used as the functional analysis for this study. The details of the description are set out in Table 1 and 2. 


\section{DISCUSSION AND ANALYSIS}

A second part of the analysis looked the nature of extension policy extent in each country. Three forms of formalized national extension policy occur in industrialized, unindustrialized and transitioning nations, namely: legislated; decreed/ proclaimed; and provisional (FAO, 1998). However, many countries have no formal extension policy. Thus, for these countries the study adopted the idea of de facto policy, the substance of which was extracted and otherwise inferred from relevant documents published either by the nation state itself, themselves and/or from some other credible sources such as the FAO and IFPRI. This extraction process was also used for those nations where provisional policy was reported to be existing, but where no copy or summary thereof could be located.

Table 1

Elements, Descriptions and Criteria for Measurement of Agricultural Extension System

\begin{tabular}{|c|c|c|}
\hline Elements & Descriptions & Criteria of Measurement \\
\hline $\begin{array}{l}\text { Nature of the } \\
\text { extension policy }\end{array}$ & $\begin{array}{l}\text { Classification of the various extension policies based } \\
\text { on their degree of formality and informality }\end{array}$ & $\begin{array}{ll}\text { - } & \text { Legislated } \\
\text { - } & \text { Decree/Proclamation } \\
\text { - } & \text { Provisional } \\
\text { - } & \text { de facto }\end{array}$ \\
\hline $\begin{array}{l}\text { Mission and } \\
\text { Goals }\end{array}$ & $\begin{array}{l}\text { Mission: Broad enduring statement of purpose that } \\
\text { distinguishes the organization and identifies the scope } \\
\text { of its operations (Smith, Ronald, Paula and Kerry, } \\
\text { (n.d.), citing Pearce, } 1982 \\
\text { Goals: Changes required to fulfill mission \& move } \\
\text { toward vision; Long-range change targets } \\
\text { Functions: } \\
\text { - Articulate organization's uniqueness } \\
\text { - } \quad \text { Build shared sense of purpose } \\
\text { - } \quad \text { Shape employees' focus } \\
\text { - Communicate strategic direction } \\
\text { - } \quad \text { Guide strategic planning. } \\
\text { - Portend resources to be committed } \\
\text { What to look for in an extension policy: } \\
\text { - Establish the primary and secondary focuses } \\
\quad \text { of the policy }\end{array}$ & $\begin{array}{l}\text { Mission: } \\
\text { Agricultural Development } \\
\text { Human Resource Development } \\
\text { Sustainable Agriculture } \\
\text { Goals: } \\
-\quad \text { Improve Profitability } \\
-\quad \text { Increase Production } \\
-\quad \text { Provide Stability of } \\
\quad \text { production } \\
\text { - } \quad \text { Social Development }\end{array}$ \\
\hline
\end{tabular}

Clientele in Table 2 denotes the various groups of customers of extension services. The variety comprises of women, youth, farmer organizations, small-, medium-, and large-scale farmers, as well as landless and specific commodity farmers. These groupings are significant to the outlining features of clientele such as gender, age and scale of farming. It is acknowledged that the different clientele may have various working relationship with extension agents, however, the nature of such relationship types is outside the considerations of this paper and the range presented in Table 2 is used. 
Table 2

Elements, Descriptions and Criteria of Measurement

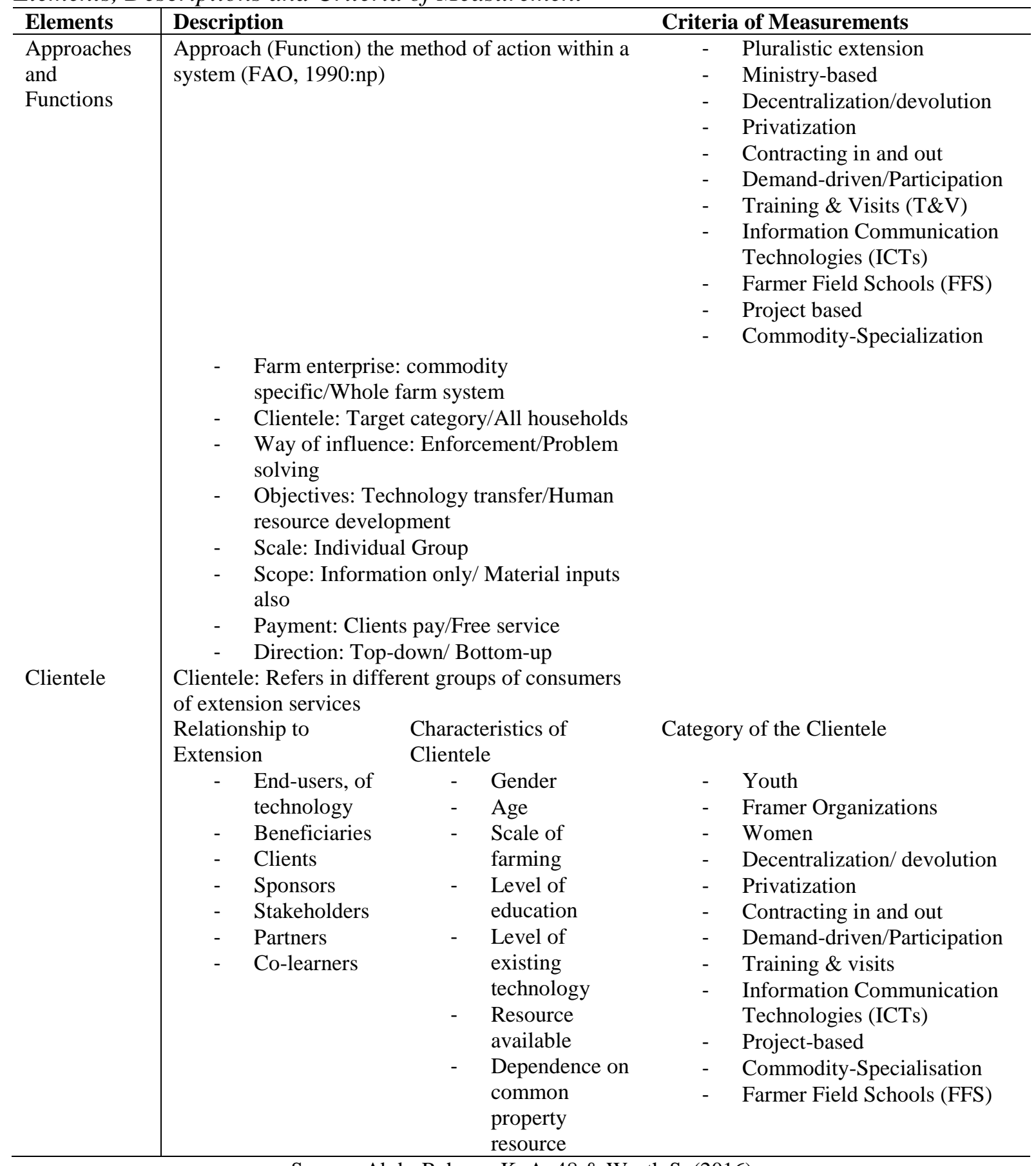

Source: Abdu-Raheem K. A. 48 \& Worth S. (2016)

\section{Composition of Countries in the Study}

The United Nations scheme of geographic regions (2013) identifies 17 countries as constituting the West Africa. However, only two of these countries were selected for this comparative study. These are The Gambia and Nigeria.

Table 1 also considers the mission and goals of extension policy. This effort determined that the universal mission of most national agricultural policies in West Africa particularly Nigeria and The Gambia centres on agricultural development, human resource development, and sustainable agricultural and rural development. Similarly, the principal goals are found revolving around enhancing profitability of agricultural trade, growing the volume of 
productivity and market share, providing stability in terms of food obtainability and production through all time of the year, and for non-monetary shared purposes like improving environmental health and value and overall advancement of the quality of life for the masses.

Concerning the approaches and function element in Table 1 and 2, literature is supplied with several descriptions for extension approach, such as specified in Bolliger, Reinhardt \& Zwellweger, 1994, Hagmann \& Shultz, 2000, and Leeuwis, 2004. When considered from various literature, the term "approaches" appeared problematic in its explanation, thoughtfulness and usage. The works of Blum (2007), Worth (2006), and Abdu-Raheem \& Worth, (2011) used the term as synonymously discussing general modes of extension such as linear, advisory, facilitation and learning. Contrary wise, writers like Rivera (1988), Axinn (1998), Gemo, Eicher \& Teclemariam (2005), and Davis (2008) denoted the conception as signifying detailed models such as Pluralistic, Training \& Visit (T\&V), and Farmer Field Schools (FFS) shown in Table 2. This work takes on the latter, more explicit, viewpoint.

\section{Cross-Examining Extension Policy in Nigeria and The Gambia}

The outcomes from investigating the extension policies in West African countries are offered in this section.

\section{Analysis of Agricultural Extension Policies of Nigeria and Gambia}

Table 3

National Extension Policy of Nigeria and The Gambia

\begin{tabular}{l|lll}
\hline Concepts & Components & Nigeria & Gambia \\
\hline Policy Form & Legislated & N & N \\
& Provisional & Y & Y \\
& Degrees and Proclamations & N & N \\
& Extracted/Implied & Y & Y \\
\hline
\end{tabular}

Source: Abdu-Raheem K. A. 48 \& Worth S. (2016)

\section{National extension policies in Nigeria and The Gambia}

Table 3 presents the evaluation of results for the extension policies between Nigeria and The Gambia. It uses the framework of nature of extension policy, mission and goals, approaches and functions, and clientele as described in Table 1 and 2.

The study primarily documented the presence of extension policy in the two countries comprised in the study, as well as the nature or form of its existence. As presented in Table 3, none of the two countries possesses a legislated extension policy and all of them assert having a provisional and extracted extension policy. Nonetheless, for the purpose of this study, both of them have de facto policies.

Discovering only one formally published national extension policy among the two countries is an attestation, to an extent, to the findings of Oladele (2011) who indicated only three from among 27 sub-Saharan Africa nations covered in his inquiry as operative on legislated type of extension policy. He revealed the bulk were running provisional type of policy.

This paper stresses the imperative that all national governments in the two develop nation-wide structure in form of officially embraced policy to direct extension delivery. This is consistent with the assertion made by the Secretariat of the Pacific Community (2010: n. pag.) that, "the absence of clear policy frameworks has resulted in services which lack a clear understanding of what their core functions should be, how they should allocate scarce resources, what training extension officers require to carry out their role effectively, and how they can work better with other partners, including the private sector, and with new technology to improve their services". 


\section{Mission and Goals}

Table 4

Mission and Goals of Nigeria and The Gambia

\begin{tabular}{l|lll}
\hline Concept & Components & Nigeria & The Gambia \\
\hline Mission \& & Agricultural development & Y & Y \\
Goals & Human Resource Development & N & Y \\
& Sustainable Agricultural \& Rural Development & N & Y \\
& Improve Profitability & Y & Y \\
& Increase Volume & Y & Y \\
& Provide Stability & Y & Y \\
& Non-Monetary & N & N \\
\hline
\end{tabular}

Source: Abdu-Raheem K. A. 48 \& Worth S. (2016)

The mission declarations of national extension policies in West Africa, as well as in Nigeria and The Gambia as shown in Table 4, generally target agricultural and human resource development, which is most often translated into concentrating on improving profitability and volume of agricultural production. This tendency to translate these into essentially agricultural production goals is likely due to the pressure created by the significant level of food insecurity and poverty in West Africa, coupled with the dominance of smallholder farmers in the agricultural landscape (Salami, Kamara \& Brixiova, 2010). Notwithstanding the immediate urgency, however, extension intervention needs to go beyond the shorter-term offering of technical assistance relating to farming, to contextualising services within a broader livelihood framework in which the farmers function to produce more sustainable change. Abdu-Raheem and Worth (2011) maintained that agricultural extension, through building farmer capacity to manage their farming enterprises, manage their social and environmental sustainability contexts and to deliberately engage in scientific enquiry (learning) can profoundly help realise sustained enhanced food security and enriched livelihoods for smallholder farmers.

While not necessarily cross-examining the rightness of the general mission and goals of extension policies in West Africa and in Nigeria and The Gambia in particular, the absence of any explicit reference to environmental sustainability, constitutes a great concern given the pressure globally placed on natural resources. Paying attention to environmental sustainability as an integral part of the mission and goals will not only help realise enhanced productivity and profitability for poor farmers but will also assist in preserving the natural resource base upon which the aggregate livings of these farmers mostly hinged.

\section{Approaches and functions}

Table 5

Approaches and Functions of Extension Services in Nigeria and The Gambia

\begin{tabular}{l|lll}
\hline Concept & Components & Nigeria & The Gambia \\
\hline Approaches and Functions & Pluralistic Extension Provider & $\mathrm{Y}$ & $\mathrm{N}$ \\
& Ministry-Based & $\mathrm{N}$ & $\mathrm{N}$ \\
& Decentralization/Devolution & $\mathrm{Y}$ & $\mathrm{Y}$ \\
& Privatization & $\mathrm{Y}$ & $\mathrm{Y}$ \\
& Contracting in and out & $\mathrm{Y}$ & $\mathrm{N}$ \\
& Cost-Sharing & $\mathrm{N}$ & $\mathrm{N}$ \\
& Demand Driven/Participatory & $\mathrm{Y}$ & $\mathrm{Y}$ \\
& Free-For-Service & $\mathrm{N}$ & $\mathrm{N}$ \\
& Training \& Visits (T \& V) & $\mathrm{N}$ & $\mathrm{N}$ \\
& Information Communication Technologies (ICTs) & $\mathrm{N}$ & $\mathrm{N}$ \\
& Farm Field Schools (FFS) & $\mathrm{Y}$ & $\mathrm{Y}$ \\
& Project & $\mathrm{Y}$ & $\mathrm{N}$ \\
& Commodity-Specialized & $\mathrm{N}$ & $\mathrm{Y}$ \\
\hline
\end{tabular}

Source: Abdu-Raheem K. A. 48 \& Worth S. (2016)

As presented in Table 5, agricultural extension in Nigeria and The Gambia is deployed in a variety of ways. These include decentralization, privatization, demand-driven/participatory 
approach and outsourcing of extension services in the context of adopting pluralistic system of extension delivery. Eicher (2007: 5), while recognizing that about six extension models are commonly being adopted all over unindustrialized countries, noted that "virtually every developing country now has a mixture of public, NGO and private firms' delivery extension system assistance to smallholders". The recognition and common adoption of a pluralistic model is conceivably the utmost necessary change in African agricultural extension (Davis 2006; Birner \& Anderson, 2007).

Pluralism as an approach recognises the important distinctions existing among farmers, farmers' needs and requirements and farming systems, and the inevitability to address these variations by means of diverse methodologies, services and service providers. With the embrace of pluralism, farmers enjoy access to a broadened collection of service options, thereby resulting in value-added quality of services to farmers. Rivera and Alex (2004) observed in literature increasing justification for less involvement of governmental in extension activities within the context of pluralistic delivery. However, they argued that in a pluralistic system the governmental role only changes in form of extension delivery; in reality the governmental role does not diminish. Extension institutions - public, private or otherwise - will continuously need governmental support of certain critical services, ranging from response to tragedies, risk bearing and sharing, regulation, quality control, system harmonization, and promotion of reform.

Decentralization is another strategy widely practiced as a part of reforming extension in the two countries. The mostly common use of decentralization retains the public sector and public funding features of traditional centralized extension but redistributes responsibility for extension delivery and reassigns it to local, district, and/or county, governments. Key inherent challenges of decentralization, however, are lack of financial sustainability, the propensity to use extension agents for jobs outside their responsibilities, and the trouble in linking with research (Anderson \& Feder, 2004).

Concurrently with decentralization, few countries have also implemented privatization of extension services in which system farmers share with the state responsibility for funding extension services. This lightens the financial burden ordinarily exclusively shouldered by the public (Anderson and Crowder, 2000). However, there appear to be varying forms of privatization with correspondingly varying depths of governmental involvement. As stated by Kidd, Lamers, Ficarelli \& Hoffmann (2000: 97), the contemporary privatisation expressions "vary from a complete withdrawal of state interventions, to a commercialisation and costrecovery approach (via levies, user charges and contracting public sector services), to an increased involvement of the public services in income generating activities, which includes the sale of seeds, surplus land and produce as well as the sale of publications and other materials". Nevertheless, Eicher (2007: 6) argued that insufficient evidence exists to date as to whether small farms, by being responsible for any of these costs, can ever "buy their way out of poverty". Equally to the decentralized ministry-based approach that is popularly gaining adoption among East Africa countries, Table 3 shows that a Nigeria and The Gambia does not have no centralized ministry-based extension systems. This centralized system of extension provision has been criticized severely and consistently for its lack of efficiency. Evidence is, however, currently lacking on whether there are on-going efforts towards reformation of extension management in these countries. Nonetheless, this study suggests it as a necessary step for national governments in these countries and in West Africa as a whole, to re-evaluate their extension organization, management and approaches based on the needs of their general 
clientele profiles and the mission and vision of their agricultural and national development objectives. What is clear from Table 3 is that the tendency is toward pluralistic extension services, comprising a combination of public and private service provision with varying degrees and forms of centralization.

Irrespective of the approach - decentralization, ministry-based, privatization, or pluralistic being employed by the two countries and West African nations, the majority have adopted the Farmer Field School (FFS) method to delivering extension. The FFS model is a communitybased learning arrangement first introduced in Asia in the wake of Green Revolution as a remedial reaction to misuse of insecticides on irrigated rice fields (Gallagher, Braun \& Duveskog, n.d.). It was introduced to sub-Saharan Africa in the mid-1990s (Davis, 2008); and currently, about 27 sub-Saharan states are practicing it (Braun, Jiggins, Röling, Van Den Berg \& Snijders, 2005). The learning technique in the model is practical and participatory, with a profound objective of developing field school participants into "confident [integrated pest management] experts, self-teaching experimenters, and effective trainers of farmers and extension workers" (Wiebers 1993: 32). FFS is an iterative and intensive learning process aimed "bringing better yields, fewer problems, increased profits and less risk to their health and environment" (Braun \& Duveskog, 2008: 6 citing Dilts, 2001). Its adoption is consistent with the decentralized and demand-driven approaches adopted by West African countries including the two countries. But, it is less consistent with the singular focus on increased volumes adopted by most West African countries. This suggests there might be a disconnection between high level intention and on the ground practice.

Owing to its high implementation cost (relative to more traditional extension approaches), a major query raised about the FFS model is its financial sustainability. Quizon, Feder \& Murgai, (2001a \& b) submitted that the intense training activities per farmer taught are expensive. This often translates into less farmer coverage on a nationwide scale (Anderson \& Feder, 2004). This suggests the necessity for a careful cost-benefit evaluation of FFSs to determine when and where it is justified particularly in terms of marginal returns, and whether states (particularly West African countries) can carry on funding it subsequent to the withdrawal of external aid. Unswerving with the adoption of the FFS approach, Table 5 shows that demanddriven/participatory approaches are similarly broadly employed among the two countries. This is also consistent with current trends in extension transformation which place emphasis on demand-driven approaches to extension provision (Neuchatel Group, 2006). 'Demand-driven', necessarily, suggests that services are supplied in line with people's requests. It operates on two other core philosophies: service providers are accountable to users; and a wide-ranging choice of service providers is accessible and available to users (Abdu-Rahma \& Worth, 2016 in Neuchatel Group, 2006). 'Demand-driven' signifies a departure from standard top-down approach used in most public-sector services and is part of the movement toward responsive governance in public sector reformation.

The demand-driven approach, if not properly and carefully guided, can negatively impact communal benefits. This proposes that exclusive reliance on farmer-led demands, may lead to the provision of services that are of exclusive and often short-term importance to the farmers willing and able to pay, without necessarily considering longer-term externalities such as environmental pollution. The Neuchatel Group (2006), nevertheless, maintained that the tendency for self-centered 'demands', does not nullify its role as a strategy to deliver public extension. The tendency can be mitigated with appropriate financial incentives to encourage farmers to request services that will align with longer-term externalities needed to ensure 
sustainability. In addition, to achieve success with this approach, governments need to discontinue offering those services which could better undertaken and delivered by the private sector, while they assist in establishing policies to empower and strengthen the approach.

As shown in Table 3, the use of information and communication technology (ICT) is another approach that is increasingly being adopted in Nigeria and The Gambia and West Africa as a whole. This is not surprising considering the rapid expansion of both the infrastructure and use of ICT (especially the Internet and cell phones) (Aker, 2011). In 1999, fewer than $10 \%$ of subSaharan Africa's population had mobile phone coverage; by 2008, this had increased to above $60 \%$. This growth translated into an increase in the number of mobile phones subscribers from16 million in 2000 to 376 million by 2008 Aker \& Mbiti (2010).

The use of ICT-based approach in agricultural extension services began about 2007 through the supply of mobile-based applications offering important information including market demand and prices, meteorological conditions, transportation and agricultural advice through voice, short message service (SMS), radio and internet. Despite its reported growth, there is little empirical evidence of the impact of ICT in agricultural (Aker, 2011). Still the potential is substantial. ICT-based extension can enhance accountability of extension agents to farmers (Duflo, Hanna \& Ryan, 2007; Dillon, 2012). It can facilitate credit and savings to farmers (Foster \& Rosenzweig, 2010), access by farmers to private information (Baye, Morgan, \& Scholten, 2006; Aker, 2010), and the capacity of farmers to manage input and output supply chains (Aker, 2011). In this vein, various ICT agricultural extension programmes have been found in both countries and other West African countries including projects such as: ICT Support for Agricultural Literacy in Ghana; Esoko in Benin, Ghana and Nigeria; West Africa Agricultural Market Information System in Niger, Ghana and Nigeria; and InfoPrix Benin (Aker, 2011).

\section{Clientele}

Table 6
\begin{tabular}{c|lll} 
Clientele of Extension Systems in Nigeria and The Gambia \\
\hline Concept & Components & Nigeria & The Gambia \\
\hline Clientele & Women & Y & Y \\
& Youth & N & Y \\
& Farmers Organization & N & Y \\
& Small-Scale Farmers & Y & Y \\
& Medium-Scale Farmers & Y & Y \\
& Large-Scale Farmers & N & N \\
& Landless Farmers & N & N \\
& Specific commodity Farmers & N & N \\
\hline
\end{tabular}

Source: Abdu-Raheem K. A. 48 \& Worth S. (2016)

Table 6 indicate that all the two countries the extension policies focus extension provision towards women, and small- and medium-scale farmers. Smallholder farmers particularly, in terms of production scale, control agricultural production in both countries as well as West Africa; hence, their significance for economic development cannot be overstressed. Enhancing the capacity and productivity of smallholder farmers and their farms is a key to reducing poverty in both countries and West Africa (Bahram \& Chitemi 2009; World Bank, 2008). Wiggins (2009: 11-12) identified five things that would increase the capacity of smallholder farmers to contribute to poverty alleviation: (1) "Creating a favourable investment climate for farming"; (2) "Investment in public goods that support agriculture, most notably agricultural research and extension"; (3) "Developing economic institutions to allocate and protect property rights, to facilitate trading, to reduce risk and to allow collective action"; (4) enhancing and capitalizing on the demand at the farm gate; and (5) supporting farmers in the conservation of their "land, 
water and other natural resources so that physical production can be sustained". In each of these, extension services have an obvious role to play - and further justifies the focus of extension policy on smallholder farmers.

Despite their importance, significant challenges militate against providing extension services to smallholder farmers: inadequate funds for public extension; poor resourcing; lack or insufficient participation of farmers in planning and design of programmes and technologies; insufficient coverage of extension throughout the region; and technical challenges in adjusting technology options to circumstances of farmers (IFPRI-World Bank, 2010). Exacerbating the provision of extension to smallholder farmers is the particular difficulty of delivering extension to women due to women's lack of access and control over productive capital and essential technical knowhow appropriate for their circumstances (Quisumbing \& Pandolfelli, 2010; Swanson \& Rajalahti, 2010). Clearly there is a need for national extension policies in West Africa identifying the necessity to prioritise female smallholder farmers and give particular attention to eradicating the impediments inhibiting women from acting on extension advice.

\section{CONCLUSION AND RECOMMENDATIONS}

This analysis has brought to the fore the significance of the need for apposite national extension policies to ensure effective planning and provision of agricultural extension. It has primarily emphasized an outline for rigorous national extension policy and system, the three crucial components of which are: mission and goals; approach and functions; and clientele. These same components were used to assess the prevailing national extension policies in West African countries.

The study found that the majority of the West African states including Nigeria and The Gambia do not have official extension policies. In most circumstances the study had to rely on de facto policy extracted indirectly and thus recommend that, without recognized policies, it will be difficult to provide farmers dependable and effective support that operates in a situation of longterm sustainability.

The official and de facto policies assessed demonstrated that the missions of most West African extension like Nigeria and The Gambia focus on agricultural and human resource development but in the situation of improving profitability and volume of agricultural production. In all of the nations, this review established that the extension services are changing and being reformed. There is movement towards decentralization, expanding privatization of extension services and introducing demand-driven, 'for pay' extension, all within the agenda of adopting a pluralistic system of extension delivery. Despite the fact that the two countries have embraced FFS in their set of services, the principal approach of extension appears still to be technology transfer together with information sharing with a distinguished increase in the use of ICT. The major clientele of extension in Nigeria and The Gambia are the smallholder farmers, with some attention to offering services to women who are confronted with particular challenges in responding extension advice.

Thus, it would seem that the objective of extension in the two countries and West Africa as a whole is to support smallholder farmers to develop their capability to farm through adoption of technology which will then assist them to increase the volume and profitability of production. To address the slow and varying agricultural production growth rate and inequitable household food security suffered in sub-Saharan Africa (relative to the world over), this analysis recommends that extension policy needs to be formalized to generate a stable agenda for planning and implementing. It further recommends that the policies offer appropriate structures that will sincerely help farmers realize their potential which the past years of extension have 
been unable to achieve. This is a sine qua non to providing the type of agricultural extension that can bring about the desired growth of the agricultural sector in the two countries and SubSaharan Africa.

\section{References}

Abdu-Raheem K. A., \& Worth S. (2016). Suggesting A New Paradigm for Agricultural Extension Policy: The Case of West African Countries. South African Journal of Agricultural Extension, 44(2), 216-230

Abdu-Raheem, K. A. \& Worth, S. H. (2011). Household Food Security in South Africa: Evaluating Extension's Paradigms Relative to the Current Food Security and Development Goals. South African Journal of Agricultural Extension, 39(2), 91-103.

Aker, J. C., \& Mbiti, I. M. (2010). Mobile phones and economic development in Africa. Journal of Economic Perspectives, 24(3), 207-232.

Aker, J. C. (2010). Information from markets near and far: Mobile phones and agricultural markets in Niger. American Economic Journal: Applied Economics, 2, 46-59.

Aker, J. C. (2011). Dial "A" for agriculture: a review of information and communication technologies for agricultural extension in developing countries. Agricultural Economics, 42, 631-647.

Alex, G., Zijp, W., \& Bylerlee D. (2002). Rural Extension and Advisory Services: New Directions. Rural Development Strategy Backgroup Paper No. 9. Washington, D.C., Agriculture and Rural Development Department, World Bank.

Anderson, J., \& Crowder, L. V. (2000). The Present and Future of Public Sector Extension in Africa: Contracting-out or Contracting-in? Public Administration and Development, 20, 373-384.

Anderson, J. R., \& Feder, G. (2004). Agricultural extension: Good intentions and hard realities. World Bank Research Observer, 19(1), 41-60.

Axinn, G. H. (19880. 'T \& V (tragic and vain) extension? Interpaks Exchange. International Agriculture, 5(3), 6-7.

Barham, J., \& Chitemi C. (2009). Collective action initiatives to improve marketing performance: lessons from farmer groups in Tanzania. Food Policy, 34, 53-59.

Baye, M., Morgan, J., \& Scholten, P. (2006). 'Information, search and price dispersion' in Handbook on Economics and Information Systems, T. Hendershott (ed.), Elsevier Press, Amsterdam.

Birner, R., \& Anderson, J. R. (2007). How to Make Agricultural Extension Demand - Drive? The Case of India's Agricultural Extension Policy, ISNAR/INPRI Draft, Washington, D.C.

Blum, M. L. (2007). Trends and Challenges in Agricultural Extension - Policies and Strategies for Reform, presented at the "Building Partnerships for Technology Generation, Assessment and Sharing in Agriculture among West Balkan Countries' Workshop", Skopje 27-29 June 2007. www.fao.org/nr/res/wshops/docs/Presentation2.Pdf [Accessed May 2011].

Bolliger, E., Reinhardt, P. \& Zwellweger T. (1994). Agricultural Extension: Guidelines for extension workers in rural areas. SKAT, Swiss Centre for Development Co-operation in Technology and Management, Switzerland. 
Braun, A., \& Duveskog, D. (2008). The Farmer Field School Approach - History, Global Assessment and Success Stories. Paper commissioned by the International Fund for Agricultural Development. IFAD: Rome

Braun, A., Jiggins, J., Röling, N., Van Den Berg, H., \& Snijders, P. (2005). A global survey and review of Farmer Field School experiences. Nairobi: International Livestock Research Institute.

Davis, K. E. (2006). Farmer field schools: A boon or a bust for extension in Africa. Journal of International Agricultural and Extension Education, 13(1), 91-97.

Davis, K. E. (2008). Extension in Sub-Saharan Africa: Overview and Assessment of Past and Current Models and Future Prospects. Journal of International Agricultural and Extension Education, 15(3), 15-27.

Dillon, B. (2012). Using mobile phones to collect panel data in developing countries. Journal of International Development, 24(4), 518-527.

Duflo, E., Hanna, R., \& Ryan, S. (2007). Monitoring works: getting teachers to come to school, NBER Working Paper No. 11880, 2005; BREAD Working Paper No. 103.

Eicher, C. K. (2007). Agricultural Extension in Africa and Asia. Ithaca, New York: World Ag Info Project, Cornell University.

FAO, (2012). World Agriculture: Towards 2030/2050 - The 2012 Revision, FAO, Rome.

Farrington, I. C., Kidd, A. D., \& Beckman, M. (2002). Extension, poverty and vulnerability: The scope for policy reforms (Final report of a study for the Neuchatel Initiative); Working paper No. 155. London, UK: Overseas Development Institute; March.

Foster, A., \& Rosenzweig, M. (2010). Microeconomics of technology adoption. Annual Review of Economics, 2, 395-424.

Gêmo, H., Eicher, C. K., \& Teclemariam, S. (2005). Mozambique's experience in building a national extension system, East Lansing, Michigan State University Press, Michigan.

Ifpri/Fao/Iica Worldwide Extension Study. (2011). Agricultural extension and advisory services worldwide. http://www.worldwide-extension.org/africa/ [Accessed February, 2016].

Ifpri-World Bank, (2010). Gender and governance in rural services: Insights from India, Ghana, and Ethiopia. Washington, DC: Agriculture and Rural Development, World Bank.

IMF, (2010). World Economic and Financial Survey. Regional Economic Output. Sub-Saharan Africa. Resilience and Risks, IMF.

Leeuwis, C. (2004). Communication for rural innovation: rethinking agricultural extension (3rd Ed.). Blackwell Publishing, Oxford.

Neuchâtel Group., (2006). Demand driven agricultural advisory services. Accessed: 26/08/2015. Available from website:

http://www.neuchatelinitiative.net/english/documents/DemandDrivenAgriculturalAdvis o ryServices.pdf (accessed 24 July 2018).

Oladele, O. I. (2011). Agricultural extension policy: The missing link in innovations in extension and advisory services. Paper presented at the International Conference on Innovations in Extension and Advisory Services- Linking Knowledge to Policy and Action for Food and Livelihoods, Nairobi, Kenya. Nairobi. Retrieved from http://extensionconference2011.cta.int/node/438

Quisumbing, A. R., \& Pandolfelli, L. (2010). Promising approaches to address the needs of poor female farmers: Resources, constraints, and interventions. World Development, 38(4), 581-592. Doi:10.1016/j.worlddev.2009.10.006 
Quizon, J., Feder, G., \& Murgai, R. (2001). Fiscal sustainability of agricultural extension: The case of the farmer field school approach. Journal of International Agricultural and Extension Education, 8(1), 13-23.

Rivera, W. M., \& Alex, G. (2004). The continuing role of government in pluralistic extension systems. Journal of International Agriculture and Extension Education, 11(3), 41-51.

Rosen, S., \& Shapouri, S. (2012). Factors Affecting Food Production Growth in SubSaharan Africa. http://www.ers.usda.gov/amber-waves/2012-september/factorsaffecting-foodproduction.aspx\#.U3ukI_ldWSo

Salami, A., Kamara, A. B., \& Brixiova, Z. (2010). Smallholder agriculture in East Africa: Trends, constraints and opportunities. Tunis, Tunisia: African Development Bank.

Secretariat of The Pacific Community. (2010). Developing a Policy Framework for Extension Systems Policy, Policy Brief 12/2010.

Sulaiman, R. V., \& Hall, A. J. (2003). India: the emergence of Extension-Plus: future for extension beyond technology transfer? In W.M. Rivera \& G.E. Alex, eds. Extension Reform for Rural Development. The World Bank, Washington, DC.

Swanson, B. E., \& Rajalahti, R. (2010). Strengthening agricultural extension and advisory systems: Procedures for assessing, transforming, and evaluating extension systems. ARD, World Bank, Washington, DC.

United Nations Economic Commission for Africa. (2010). Economic Report on Africa 2010: Promoting high-level sustainable growth to reduce unemployment in Africa. United Nations Economic Commission for Africa

United Nations. (2013). Composition of macro geographical (continental) regions, geographical sub-regions, and selected economic and other groupings. United Nations Statistics Division. Retrieved from http://unstats.un.org/unsd/methods/m49/m49regin.htm\#africa

Wiggins, S. (2009). Can the smallholder model deliver poverty reduction and food security for a rapidly growing population in Africa? Paper for the Expert Meeting on How to feed the World in 2050, Rome.

World Bank. (2008). The Growth Report: Strategies for Sustained Growth and Inclusive Development. Commission on Growth and Development, World Bank, Washington D.C. World Bank. (2011). Global Economic Prospects, 2011.

Worth, S. (2006). Agriflection: a learning model for agricultural extension in South Africa. The Journal of Agricultural Education and Extension, 12, 179-193. 